\title{
The Asian Yearbook of International Law 1995-2015: A Historical and Personal Reflection
}

\author{
Kevin Y.L. Tan1 1
}

\section{FOUNDING MOMENTS}

\section{INTERNATIONAL LAW SOCIETIES IN ASIA}

As the Asian Yearbook of International Law was established to realise the vision of the founders of the Foundation for the Development of International Law in Asia (DILA), a little background to DILA is in order.

A few national societies of international law existed in Asia since the turn of the nineteenth century. The oldest of them - and the first such society in the world - is the Japanese Society of International Law, founded in 1897. Republican China established what is now the Chinese (Taiwan) Society of International Law in 1913, and the People's Republic of China established the Chinese Society of International Law in 1980. In between the Indian Society of International Law was established - in 1959.

However, there was no organisation to facilitate dialogue and discourse between students and scholars on a pan-Asian basis. Indeed, the first such regional organisation was the African Association of International Law, that was established in 1986. It was against this backdrop that DILA was founded

1 Adjunct Professor, Faculty of Law, National University of Singapore; Professor, S Rajaratnam School of International Studies, Nanyang Technological University, Former Chairman, DILA, and Editor-in-Chief, Asian Yearbook of International Law. 
on 21 December 1989 by three Asian émigré international lawyers - Ko Swan Sik; JJG Syatauw and MCW Pinto - then living in the Netherlands.

\section{Ko Swan Sik and the Founding of DILA}

While it has always been the official position that the Asian Yearbook was set up to further the aims of DILA, it was in fact the vision for the Yearbook that led to the founding of DILA. The chief architect and true founding father of the Asian Yearbook was undoubtedly Professor Ko Swan Sik.

Ko was born on 4 January 1931 in Magelang in Central Java, Indonesia. His father, Ko Tjay Sing and granduncle, Ko Kwat Tiong, were both distinguished legal scholars and academics. ${ }^{2}$ Ko graduated from the Faculty of Law of the University of Indonesia in 1953 afterwhich he proceeded to the the Leiden University where he obtained a PhD (cum laude) in 1957. During his studies in Leiden, Ko spent a year at the University of Mainz and also attended the Hague Academic of International Law's summer course in 1954. He returned to Indonesia after his studies and practised as an attorney in Semarang between 1957 and 1963 before moving to Jakarta to practise. Between 1959 and 1965, he was concurrently Senior Lecturer of Public International Law at the University of Indonesia.

In February 1965, Ko left for the Netherlands where he joined the newly created TMC Asser Institute of International Law at The Hague whee, among other things, he founded the Netherlands Yearbook of International Law in 1970. In 1988, he moved to Rotterdam where he became Professor of International Law at Erasmus University. He retired and was made Emeritus Professor in 1996. In response to questions from the Journal of East Asia and International Law in 2010, Ko explained how the Yearbook and DILA came about:

... In 1983 it so happened that I was assigned to participate in the organization of an international symposium for the commemoration of the fourth centenary of the birth of Hugo Grotius. As part of the effort to emphasize the international character of the gathering I was to select and invite a number of speakers from outside Europe, particularly Asia, which I did. The ensuing broader contacts with these Asian colleagues led to the idea of starting initiatives

2 For this brief biographical account, I relied on Leo Suryadinata, Prominent Indonesian Chinese: Biographical Sketches, 4 ED (Singapore: ISEAS Yusof Ishak Institute, 2015) 102-105. 
in an Asian context and resulted in the publication, in 1990, of a multi-authored volume on a topic of international law 'in Asian perspectives 3 that was intended to be the beginning of a series under that name. Unfortunately a second volume has yet to appear.

The practical failure of continuing the 'in Asian perspective' series led, around 1988, to the alternative idea of starting a regular periodical publication which has since been the Asian Yearbook of International Law. The option for an annual rather than a higher frequency periodical was a quite conscious one but not relevant in the present context. Another aspect, however, may be quite relevant to be noted here. The possibility of financial consequences of the publication project and the wish of preventing individual persons from being burdened with such responsibility gave rise to the decision of founding a separate legal entity under whose auspices the Yearbook would be published. The entity that finally came about and that was DILA happens to be molded in the formal structure of a 'foundation' under Dutch law for the simple reason that the founders, MCW Pinto (Sri Lanka), Ko Swan Sik (Indonesia) and JJG Syatauw (Indonesia) had their residence in the Netherlands. The official founding of DILA took place on December 21,1989 by deed of a notary public in The Hague. ${ }^{4}$

Ko was, nevertheless, quick to point out that while the founding of DILA the founding of DILA was 'primarily intended to meet the contingency of financial responsibility in connection with the publication of the Yearbook', it was not 'an organization for the exclusive purpose of publishing the Yearbook'. Instead, it embodied

... a rather broad program of academic activities in the field of international law in Asia or relating to Asia, thereby aiming at promoting contacts among Asian jurists, enhancing their endeavours in the field of research and education, improving their information of whatever developments in the field of research and literature in

3 This was Ko Swan Sik (ed), Nationality and International Law in Asian Perspective (Dordrecht \& Boston: Martinus Nijhoff, 1990)

4 A Dialogue with Judicial Wisdom: Professor Ko Swan Sik (2010) 3(2) Journal of East Asia and International Law 451, at 455. 
the field concerned, and promoting the recording and dissemination of relevant Asian materials. ${ }^{5}$

\section{JJG Syatauw and MCW Pinto}

Ko's close collaborators in the DILA enterprise were Jacob Johannes Gustaaf ('Joop') Syatauw, another Indonesian international law scholar, and Moragodage Christopher ('Chris') Pinto, a diplomat and scholar. Like Ko, Pinto was born in 1931 in Colombo, Sri Lanka (then Ceylon), the son of Moragodage Walter Walter Leopold Pinto and Judith Beatrice Blazé. He was educated at the Universiity of Ceylon at Peradeniya where he graduated with an LLB degree. He then attended the Sir Lanka Law College where he qualified as an Attorney, and thereafter studied at Magdalene College, Cambridge University where he obtained another LLB degree as well as a Diploma in International Law. He was called to the at the Inner Temple in 1958. Pinto worked as a legal officer in the International Atomic Energy Agency in Vienna between 1960 and 1963, and then at the Legal Department of the World Bank from 1963 to 1967. He then returned to Sri Lanka to become Legal Advisor and Head of the Legal and Treaties Division of the Ministry of Foreign Affairs, a post he held till 1979. In 1976, he was appointed Sri Lanka's Ambassador to Germany and Austria. Pinto represented Sri Lanka at the UN Conference on the Law of the Sea between 1980 and 1981, and was, from 1982, Secretary-General of the United States-Iran Claims Tribunal till his retirement in 2011. It was during this last phase of Pinto's career that he came into contact and worked with Ko in the founding of DILA, since both of them lived in The Hague.

The third member of the DILA triumvirate was Joop Syatauw ${ }^{6}$ who unfortunately passed away on 8 February $2015,{ }^{7}$ just a year after we celebrated the Silver Jubilee of DILA. Syatauw was born on 9 December 1923 in an army camp in Bandung where his father was stationed as a Non-Commissioned Officer of the Royal Netherlands Indies Army (KNIL). His family came from the island of Ambon in the Moluccas. Sytatauw's secondary education was interrupted by the Japanese Occupation (1942-1945) and

$5 \quad$ Ibid, at 455-456.

6 Most of the following information about Professor Syatauw was kindly shared by Professor Ko Swan Sik in two emails to me, dated 20 Mar 2015 and 8 Apr 2015.

'In Memoriam' (2015) 17(1) Development Issues 9. 
worked in the Department of Mining in Bandung during the War. In 1949, he obtained a scholarship to study at Leiden where he graduated with an LLM and then proceeded to the Yale Law School where he obtained his JSD in 1960 for his thesis, Some Newly Established Asian States and the Development of International Law which was later published by Martinus Nijhoff in 1961.

After completing his doctorate, Syatauw spent some time doing additional research at the London School of Economics and Social Science. Upon his return to the Netherlands, he became assistant to Haro Fredrik Van Panhuys, Professor of International Law at the University of Leiden. At the prompting of Van Panhuys, Syatauw joined the Institute of Social Studies (ISS) in The Hague as 'Lector' - a Junior Professor, and the highest academic position at the ISS in the early 1960s - in the Department of International Law and Relations and remained there till his retirement as Professor in 1988. Ko first came to know of Syatauw around 1961 when he was still in Indonesia when 'rumours began to circulate about an Indonesian who had obtained his JSD at Yale on a dissertation on newly established Asian states.' However, it was not till 1965, when Ko relocated to The Hague that he first met Syatauw. When Ko began conceptualising the Asian Yearbook in the 1980s, he turned to Pinto and to Syatauw for support. He recalled:

When I decided to start the DILA project I decided that what I needed most was a number of people around me by way of touchstone who were able to share the essentials of my ideas and who would be approachable at any time to be consulted on the elaboration and realization of any plans. It was obvious that, next to Pinto, Joop was most qualified to be invited as a member of the team. ${ }^{8}$

\section{OBJECTS AND MODALITIES}

The three founders of DILA believed that economic and political developments in and among the countries of Asia had reached the stage that they would welcome and benefit substantially from a mechanism to promote and facilitate exchanges among their international law scholars. At the same time, they believed that a regular and reliable source of information concerning international law as applied or interpreted by states in Asia 
would be of interest to other states and contribute significantly to the progressive development of an international legal order.

Having determined that the time was not yet ripe for a pan-Asian society of international law, the founders registered DILA as a foundation or stifting in the Netherlands. This remains how the organisation is structured today. The Foundation was established to promote:

a. the study and analysis of topics and issues in the field of international law, in particular from an Asian perspective;

b. the study of, and the dissemination of knowledge of, international law in Asia;

c. contacts and co-operation between persons and institutions actively dealing with questions of international law relating to Asia.

The 'principal means by which the Foundation will seek to accomplish its aims and purposes' declared the founders, 'is publication of the Asian Yearbook of International Law.' This they did by constituting themselves as General Editors of the Yearbook with principal responsibility for its editing and publication. The rest of the Editorial Board was made up of some of the most distinguished Asian international law scholars at the time: Chang Hyo Sang (South Korea), Rahmatullah Khan (India), Onuma Yasuaki (Japan), M Sornarajah (Sri Lanka), and Sompong Sucharitkul (Thailand). Despite the inclusion of many distinguished scholars as part of the Yearbook's editorial boards through the years, right up till 2009, the three General Editors remained the persons most responsible for the its content, quality, and publication. The founding General Editors explained what they planned to do in the first volume of the Yearbook:

It is the aim of the General Editors to include in each volume of the Yearbook, in addition to scholarsly essays of an analytical, descriptive or speculative nature, materials that are evidence of the practice of States in the region. To that end the General Editors are currently engaged in trying to establish a network of correspondents in Asian countries, who would keep them currently informed of significant developments, and provide them with the associated

9 'Introduction by the General Editors' (1991) 1 Asian Yearbook of InTERnationaL LAW xi, at xiii. 
documentation on a regular basis. The problem of securing and maintaining the collaboration of scholars, all of whom are already fully engaged in routine pursuits of their own, is compounded by a variety of difficultues including variations in the efficiency of communications and the fact that no funds are available to compensae collaborators for their efforts, or even for expenses connected with providing information. Also to be included in the Yearbook are a chronicle of events relating to the region and of relevance from an international law perspective, notes on selected activities of regional and international organizations, and a survey of selected works in the field of international law.10

This statement of objectives and modalities set the template for the Yearbook in the years to come. In the 2010 revamp of the Yearbook, it was determined that the 'Chronicle' section - which was typically the longest section of the Yearbook up till this time, should cease to be prepared and published. In 1991, the Editors felt that a 'Chronicle' would record 'events and incidents relating to, or involving, Asian states and which are clearly relevant for the position of these states in international law.'11 Ko Swan Sik was personally responsible for this particular segment of the Yearbook was inspired by the 'classic' chronicle of Charles Rousseau in the Revue Generale de Droit International Public and edited it continuously from 1991 to 2009. It was time-consuming, back-breaking work, scouring newspapers, news digests and weeklies to extract news items that would make the Chronicle useful. By the mid-2000s, the section was losing its usefulness as news sites and archived newspaper databases on the internet made it so much easier for anyone wishing to tap into the news that would impact international law.

The first edition of the Yearbook was published through a guarantee from the Netherlands Ministry of Development Cooperation to purchase of 200 copies for distribution to various institutions in the Asian developing countries. The entire subvention went directly to the publishers, Martinus Nijhoff (later known as Kluwer). Thereafter, Nijhoff undertook to bear the cost of producing and marketing Volume 2 of the Yearbook, but the General Editors needed to raise more money to meet the expenses of Volume 3 which they were able to do through a Swedish International Develop-

$10 \quad$ Ibid.

11 'Chronicle of Events and Incidents Relating to Asia with Relevance to International Law, January-September 1991' (1991) 1 Asian Yearbook of International Law 265. 
ment Authority grant of US\$45,000. For the 1997 edition of the Yearbook, Professor Onuma Yasuaki convinced industrialist Mr Sata Ysuhiko ('Mike Sata') of Tokibo Co Ltd to make an annual donation to institute the Sata Prize for the best article submitted by a young (aged 35 and under) Asian international law scholar. In 2012, at the insistence of Mr Sata, this prize was renamed the DILA Prize.

In 2007, due to the lack of editorial support and ever higher and higher prices that made the Yearbook unaffordable, DILA terminated its relationship with its publisher Brill - the successor to Martinus Nijhoff and Kluwer - and commenced publishing the Yearbook with Routledge. This relationship was, unfortunately, shortlived as Routledge - who halved the subscription price of the Yearbook - found it unprofitable to continue publishing the series and terminated its contract with DILA in 2010. For five volumes thereafter, we decided to move the Yearbook to an open platform and make it available free of charge to the world at large. It was a bold move that pleased many 'consumers' since they did not need to pay for content nor subscribe to expensive databases, but worried many contributors and would-be contributors who constantly felt that their work was not being picked up by the various journal ranking services like Scopus and ISSN. Thus, it was for this reason that the DILA Governing Board decided at the end of 2016 to return to the Brill fold.

\section{REFLECTIONS}

I became associated with DILA and the Yearbook at meeting in Manila in April 1997. I was not supposed to have been at that meeting, but was asked by my senior colleague, Professor Tommy Koh, to attend the meeting on his behalf. Professor Ko Swan Sik had convened the meeting, with the assistance of the Law Faculty of the University of the Philippines to discuss succession plans for DILA. After two days, I was mysteriously 'voted' into DILA's Governing Board and onto the Editorial Board of the Yearbook as well. Over the past 20 years, I have spent much time grappling with the more practical side of running the Yearbook. The lack of funds always worried me, as did the fact that it was nigh impossible to get busy scholars to keep to a deadline insofar as production was concerned.

Yet, it had to be done. When Brill began neglecting the Yearbook in the early 2000s, I proposed that we find a more responsive publisher. We 
thought that Routledge would be the key to our continued success and longevity, but alas, a cardinal truth emerged from this experience. Commercial publishers only respond to commercial success. I then proposed that we take advantage of the internet to distribute the Yearbook for free. After all, what could be cheaper than something that was free? For readers and consumers - nothing. But for the contributors, the crushing pressure to not only publish or else perish, but to publish in 'recognised' or 'ranked' journals reinforced the stranglehold of the world's major publishers. When asked to consider submitting an article, many scholars' first question is 'Is the Yearbook a Scopus or ISSN journal?' The importance of the journal is irrelvant; neither is the quality of its content. It appears that it matters not whether a publication is peer-reviewed, only whether it sits within the stable of a journal aggregator which is penetrable only if you are a major publisher.

Twenty volumes after the first Asian Yearbook of International Law was published, its noble aims remain but DILA's second objective, to disseminate knowledge of international law in Asia, awaits fulfilment. 


\section{EDITORS OF THE ASIAN YEARBOOK OF INTERANTIONAL LAW}

\begin{tabular}{|c|c|c|c|}
\hline \multirow{2}{*}{$\begin{array}{l}\text { Editor } \\
\text { Antony ANGHIE }\end{array}$} & \multicolumn{2}{|c|}{ Years Served } & \multirow{2}{*}{$\begin{array}{l}\text { Position } \\
\text { Editor }\end{array}$} \\
\hline & 2000 & 2006 & \\
\hline Chang Hyo Sang & 1991 & 1993 & Editor \\
\hline Bhumpinder S CHImni & 1998 & 2009 & General Editor \\
\hline Diane Desierto & 2011 & 2017 & Associate Editor \\
\hline Sumaiya KHAIR & 2010 & 2017 & Editor \\
\hline Rahmatullah KHAN & 1991 & 2006 & Editor \\
\hline Kiм Charn Kiu & 1995 & 2006 & Editor \\
\hline KIM Jeong Woo & 2010 & 2016 & Associate Editor \\
\hline Kriangsak KittichairsareE & 1996 & 2006 & Editor \\
\hline Ko Kwan Sik & $\begin{array}{l}1991 \\
2000\end{array}$ & $\begin{array}{l}1999 \\
2006\end{array}$ & $\begin{array}{l}\text { General Editor } \\
\text { Editor }\end{array}$ \\
\hline LeE Hee Eun & 2010 & 2017 & Executive Editor \\
\hline James Li Zhaojie & 1996 & 2009 & Editor \\
\hline Raphael PM LотTILA & 1995 & 2006 & Editor \\
\hline Mariko KaWANo & 2001 & 2009 & Editor \\
\hline Mıyoshi Masahiro & 1998 & 2008 & General Editor \\
\hline NaKatani Kazuhiro & 1996 & 2006 & Editor \\
\hline Onuma Yasuaki & 1991 & 1995 & Editor \\
\hline MCW Pinto & $\begin{array}{l}1991 \\
2000\end{array}$ & $\begin{array}{l}1999 \\
2006\end{array}$ & $\begin{array}{l}\text { General Editor } \\
\text { Editor }\end{array}$ \\
\hline Jevaid Rehman & $\begin{array}{l}2009 \\
2011\end{array}$ & $\begin{array}{l}2010 \\
2013\end{array}$ & $\begin{array}{l}\text { General Editor } \\
\text { Editor }\end{array}$ \\
\hline Jamal SEIFI & 1996 & 2006 & Editor \\
\hline SHENG Yu & 1991 & 1997 & Editor \\
\hline
\end{tabular}




\begin{tabular}{lccl} 
Editor & \multicolumn{2}{l}{ Years Served } & Position \\
Prabhakar Singh & 2011 & 2017 & Associate Editor \\
M SoRNARAJAH & 1991 & 1997 & Editor \\
Surya P SUbEDi & 1996 & 2004 & General Editor \\
Sompong SUCHARITKUL & 1991 & 2006 & Editor \\
SUgiHARA Takane & 1996 & 2000 & Editor \\
JJG SyatAuw & 1991 & 1995 & General Editor \\
& 2005 & 2006 & Editor \\
Kevin YL TAN & 1996 & 2006 & Editor \\
& 2010 & 2017 & Editor-in-Chief \\
Thio Li-ann & 2005 & 2008 & General Editor \\
KI Vibute & 1998 & 2009 & Editor
\end{tabular}

